\title{
KONSEP DASAR DALAM MEMPELAJARI MATA KULIAH ALGORITMA PEMROGRAMAN
}

\author{
Farah Mutia Putri (0305202017) \\ Program Studi Pendidikan Matematika-2 \\ Fakultas Ilmu Tarbiyah dan Keguruan UIN Sumatera Utara \\ Jl. William Iskandar Pasar V, Medan Estate \\ Email: farahmutiaputri@gmail.com
}

\begin{abstract}
ABSTRAK
Dalam algoritma terdapat urutan langkah dalam menyelesaikan sebuah masalah. Langkah - angkah tersebut disusun secara sistematis. algoritma ialah suatu tata cara dalam mengurutkan langkah - langkah yang berintegrasi, penggunaan dalam menyelesaikan masalah memiliki metode khusus dalam penyelesai suatau masalah yg nyata(Webster Dictionary).

Algoritma memiliki tujan supaya kita dapat membiasakann diri dalam melaksanakan sistem perencanaan dari suatu masalah yang dihadapi. Dengan permasalahan tersebut dapat diselesaikan dengan perencanaan yang matang agar dalam menyelesaikan masalah kita dapat mengoptimalkan solusi yang tepat. Dengan begitu, penyelesaian masalah tidak bisa dilakukan tanpa menggunakan perencanaan. Pembelajaran suatu program sangat berbeda dengan pembelajaran suatu bahasa pemrograman. Saat pembelajaran program terdapat mengenai strategi tata cara dalam penyelesain sebuah masalah, masalah ini akan diungkapkan dalam wujud algortima yang sederhana mudah untuk dipahami dan dibaca sehingga dapat dituangkan lebih lanjut kedalam bahasa pemrograman. Belajar membuat program adalah belajar tentang strategi atau cara menyelesaikan suatu masalah, yang diungkapkan dalam bentuk algoritma yang mudah dibaca dan dipahami yang selanjutnya dituangkan dalam bahasa pemrograman. Sifat dari mempelajari program yang memahami persoalan, analisa dan sintesis.
\end{abstract}

Kata Kunci : algoritma, program, pemrograman, bahasa, langkah-langkah

PENDAHULUAN 
Programa studi pendidikan matematika memiliki mata kuliah yang ditawarkan salah satunya merupakan algoritma pemrograman. Dalam mata kuliah ini bertujuan untuk mengetahui konsep dasar pemrograman melalui algoritma, langkah - langkah algoritma serta bagaimana cara menerapkan algoritma daalm sistem pemrograman.

Saat menjalankan aktivitas kita tidak bisa lepas dari algoritma. Bisa dibilang algoritma merupakan panduan ataupun solusi yang dilakukan secara sistematis dalam menjalani atau menghadapi berbagai macam masalah yang ada disekitar. Adapun setiap langkah yang dilakukan dalam menyelesaikan sebuah permasalahan dapat dilaksanakan dengan berbagai cara beserta karakteristik yang berbeda beda di setiap masing-masing langkah.

Definisi algoritma dapat dikatakan Sebagai rangkaian langkah logis dan sistematis untuk mencari solusi dari permasalahan yang ada. Menurut Rinaldi Munir (2002), algoritma adalah serangkaian langkah logis yang digunakan untuk menyelesaikan suatu masalah, dan langkah - langkah tersebut disusun secara sistematis. Sedangkan menurut Levitin (Rinaldi, 2007:4), algoritma adalah serangkaian instruksi eksplisit untuk memecahkan masalah, memperoleh keluaran yang diinginkan dari sejumlah masukan yang terbatas.

Belajar algoritma hampir sama dengan belajar matematika, jika dalam matematika kita harus memahami rumus terlebih dahulu sebelum bisa mendapatkan hasil soal, begitu juga dengan algoritma dan prosedur, kita harus terlebih dahulu memahami kode - kode tertentu yang disebut coding agar kita dapat menjalankan program dan menuangkannya ke dalam beberapa jenis simbol yang mudah dibaca dan dipahami.

Algoritma mempunyai beberapa karakteristik, yaitu :

1. Menerima beberapa masukan.

2. Memproses masukan melalui langkah-langkah yangberurutan.

3. Setiap langkah harus didefinisikan dengan jelas,sederhana, danefektif.Urutan langkah tersebut harus terbatas dan berhenti.Menghasilkan keluaran atau output.

Pemrograman adalah proses implementasi algoritma dengan menggunakan bahasa yang sudah ada dalam sistem pemrograman (Budi, 2000:21). Tujuan 
pemrograman adalah kita dapat melakukan perhitungan atau pekerjaan sesuai kebutuhan saat menulis program. Oleh karena itu, untuk memprogram, kita memerlukan keterampilan algoritma.

Pemrograman berasal dari kata "program", yang berarti serangkaian instruksi yang ditulis untuk melakukan fungsi tertentu pada komputer, dan pemrograman adalah aktivitas apa pun yang digunakan komputer untuk membuat program. Sebuah komputer membutuhkan program untuk menjalankan fungsinya sebagai komputer.

Bahasa pemrograman memiliki beberapa ciri, yaitu:

1. Memiliki tata bahasa dan aturan tertentu dalam penulisan perintah dan struktur program, pendeklarasian, sertapengoperasian translatornya.

2. Terdapat perpustakaan interupsi untuk menerjemahkan perintah input, dan

3. Gunakan penerjemah, yaitu juru bahasa atau kompiler, untuk menerjemahkan tata bahasa pemrograman ke dalam bahasa mesin komputer.

Dalam pemrograman, bahasa yang disebut turing complete dapat digunakan untuk menggambarkan semua perhitungan yang dilakukan oleh mesin Turing. Mesin Turing memiliki variabel integer dan operator aritmatika, pernyataan penugasan, pernyataan sekuensial, pernyataan pemilihan, dan pernyataan iterasi. Pernyataan-pernyataan tersebut digunakan mesin Turing didefinisikan secara formal oleh konsep matematika.

\section{Metode Penelitian}

Metode yang digunakan dalam penelitian ini berasal dari buku sebagai referensi beserta jurnal yang diterbitkan. Dalam penelitian ini jurnal penelitian terkait dengan teori dan konsep dasar algoritma perograman, metode/teknik/strategi dalam algoritma pemrograman. Bentuk ringkasannya adalah algoritma dan bahasa yang ada di dalam pemrograman yang akan digunakan, strukukturnya, siapa objek penelitiannya, dan penerapan dalam kehidupan, beserta contoh-contoh teknik tersebut.

Ada beberapa ketentuan dalam mengerjakan menyelesaikan peneletian ini,yaitu: 
1. Ketentuan pertama dalam penelitian ini harus memiliki referensi minimal 10 jurnal. Jurnal - jurnal tersebit harus terdapat beberapa tema yang sudah ditentukan. Selain itu, yang harus dipenuhi yaitu jurnal dimulai pada tahun 2015.

2. Ketentuan kedua dalam penelitian ini harus memiliki refensi minimal dari 2 buku. Buku yang dipilih dalam renferensi penelitian ini yaitu pertama berjudul "Algortma \& Pemrograman Dalam Bahasa $\mathrm{C}++$, penulis buku ini ialah Uce Indahyanti, M.Kom danYunianita Rahmawati, M.Kom.. Buku kedua berjudul "Logika dan Algoritma", penulis buku ini ialah Ali Ridho Barakbah, S.Kom., PhD., Tita Karlita, S. Kom., M. Kom. Dan Ahmad Syauqi Ahsan, S. Kom. Di dalam buku terdapat materi mengenai materi algoritma pemrograman dan terdapat contoh - contoh penerapan algoritma dalam kehidupan.

3. Ketentuan ketiga dalam penilitian ini minimal kata yang ada dalam penelitian ini berjumlah 3000 kata.

Istilah algoritma berasal dari istilah "algoritma" dan mengacu pada Seorang matematikawan Muslim yang hidup pada abad ke-19 bernama Ibnu Kharazmi. Dalam perkembangannya, ide - idenya Jelaskan dan selesaikan masalah secara logis diterapkan sebagai metode algoritma dalam matematika Proses kerja komputer.

Di dalam penelitian ini akan dijelaskan mengenai pengertian algoritma, konsep algoritma, notasi algoritma,ciri, sifat dan struktur dasar dalam pembelajaran algoritma beserta langkah langkah dalam pengerjaan algoritma pemrograman . Penelitain ini juga akan menjelaskan mengenai apa saja perbedan algoritma dengan pemrograman dan dari perbedaan tersebut akan dijelaskan hubungan antara algoritma pemrograman.

\section{PEMBAHASAN}

\section{Algoritma}

Algoritma adalah sistem komputer yang memiliki perangkat otak (brainware), perangkat keras (hardware) dan perangkat lunak (software). Tanpa ketiga hal tersebut sistem komputer tidak akan berfungsi. Saat kita fokus memperhatikan 
perangkat lunak (software) komputer. Perangkat lunak ini dibangun di atas Struktur program dan tata bahasa (cara menulis/pemrograman). Menulis Prosedur atau tata bahasa, langkah - langkah yang diperlukan. Mampu secara sistematis dan logis. Masalah atau tujuan dalam proses pemecahan. Membuat perangkat lunak. Nah, algoritmanya. Memainkan peran penting dalam pemrograman Atau tata bahasa.

Algoritma yang paling penting memiliki dua struktur dasar, yaitu:

1. Gunakan sistem belajar mandiri (bahan belajar mandiri) dan simpan di komputer. Sehingga dosen dapat berkunjung kapan saja dan dimana saja.

2. Gunakan komputer untuk melihat kemajuan belajar, jadwal kurikulum, hasil kemajuan belajar, dan hal-hal yang berhubungan dengan pendidikan setiap saat.

Algoritma adalah serangkaian langkah logis untuk memecahkan masalah Compose secara sistematis. Algoritma yang disebutkan dalam referensi lain adalah suatu proses, yang merupakan serangkaian langkah-langkah terintegrasi, atau metode khusus untuk memecahkan masalah praktis (Webster Kamus).

Kita juga telah melakukan algoritma dalam kehidupan kita sehari-hari, Seperti mengirim email, menginstal aplikasi, menerima pembayaran di ATM, isi ulang poin, buat kue, naik motor, dll.

Berikut beberapa contoh mengenai algoritma dikehidupan sehari-hari:

Contoh 1 : Mengendarai sepeda motor:

1. Mulai

2. Memasukkan Kunci

3. Menyalakan Mesin

4. Memasukkan Gigi Satu

5. Memutar Pegangan Gas

6. Menjalakan

7. Menaikkan Sepeda

Contoh 2 : Mengirim Email:

1. Mulai

2. Login ke situs layanan email sesuai

3. Pilih tulis email (pesan baru) 
4. Masukkan alamat mail tujuan, subjek dan tulis

Contoh 3 : Mengkoneksikan perangkat ke jaringan wifi

1. Mulai

2. Pilih jaringan wifi yang tersedia

3. Masukan username dan password

4. Jika tidak sesuai, sistem menampilkan gagal koneksi

5. Jika sesuai, koneksi internet dapat digunakan.

\section{Karakteristik, Sifat, bentuk Dasar dan Cara Penulisan Algoritma}

Menurut Donald E. Knuth, algoritma memiliki lima karakteristik yang sangat penting, yaitu:

1. .Finiteness (pembatasan), algoritma harus dihentikan setelah beberapa langkah proses telah dijalankan.

2. Definiteness (kepastian), semua tindakan harus dimaknai dengan benar, tidak berarti lebih dari satu.

3. Input (masukan), ada nol atau lebih data masukan (input) dalam algoritma.

4. Output (keluaran), terdapat algoritma memiliki nol atau lebih output

5. Effectiveness (efektivitas), langkah - langkah yang diambil saat meneliti algoritma harus tepat waktu dan berhasil.

Sedangkan sifat algoritma, yaitu:

1. .Bahasa yang ada dalam pemrograman tidak menggunakan simbol/tata bahasa tertentu

2. Bahasa pemrograman tidak bergantung pada apapun

3. Seluruh bahasa dalam pemrograman dapat digunakan dalam notasinotasinya

4. Suatu algoritma dalam merepresentasikan dapat digunakan untuk kejadian yang diurutkan secara logisdan dapat diterapkan di semua kejadian seharihari.

\section{Notasi Algoritma}

Notasi algoritma tidak merupakan notasi perograman, tetapi notasi yang dapat dijadikan sebagai notasi perograman. Notasi dalam algoritma ada sebagian hal, diantaranya:

1. Untaian Kalimat Deskriptif (Natural) 
Algoritma deskriptif adalah algoritma yang ditulis dalam kalimat dalam bahasa manusia seperti bahasa Indonesia atau bahasa Inggris. Simbol semacam ini cocok untuk aritmatika pendek, tetapi untuk simbol yang panjang, efisiensi simbol semacam ini rendah, dan konversi simbol algoritme ke simbol bahasa pemrograman seringkali relatif sulit.

\section{Pseudocode}

Pseudo-code berasal dari kata "pseudo" dan "code". Pseudo mengacu pada imitasi, dan kode mengacu pada kode yang terkait dengan instruksi yang ditulis dalam bahasa komputer atau kode bahasa pemrograman. Kode semu digunakan untuk menggambarkan urutan logis dari program dan tidak ada hubungannya dengan bahasa pemrograman.

3. Flow Chart (Diagram Alir)

Flowchart atau bagan alir adalah diagram yang menggunakan simbol atau gambar tertentu dan garis alur untuk menggambarkan urutan langkah dari awal hingga akhir suatu kegiatan atau program. Simbol mewakili fungsi langkah-langkah program dan garis arus mewakili urutan simbol yang akan diproses. Diagram alir lebih baik digunakan daripada kode semu. Jumlah simbol yang digunakan dalam flowchart sedikit karena lebih sederhana dan lebih mudah dipelajari.

Tidak ada rumusan atau patokan yang mutlak untuk membuat diagram alir program, karena diagram alir merupakan gambaran dari hasil analisis masalah komputer, sehingga hasil diagram alir dapat berbeda-beda antara programmer satu dengan programmer lainnya. 


\begin{tabular}{|c|c|c|}
\hline SIMBOL & NAMA & FUNGSI \\
\hline & TERMINATOR & Permulaan/akhir program \\
\hline & $\begin{array}{l}\text { GARIS ALIR } \\
\text { (FLOW LINE) }\end{array}$ & Arah aliran program \\
\hline & PREPARATION & $\begin{array}{c}\text { Proses inisialisasi/pemberian harga } \\
\text { awal }\end{array}$ \\
\hline & PROSES & $\begin{array}{c}\text { Proses perhitungan/proses pengolahan } \\
\text { data }\end{array}$ \\
\hline & $\begin{array}{c}\text { INPUT/OUTPUT } \\
\text { DATA }\end{array}$ & $\begin{array}{l}\text { Proses input/output data, parameter, } \\
\text { informasi }\end{array}$ \\
\hline & DECISION & $\begin{array}{l}\text { Perbandingan pernyataan, penyeleksian } \\
\text { data yang memberikan pilihan untuk } \\
\text { langkah selanjutnya }\end{array}$ \\
\hline & $\begin{array}{c}\text { ON PAGE } \\
\text { CONNECTOR }\end{array}$ & $\begin{array}{l}\text { Penghubung bagian-bagian flowchart } \\
\text { yang berada pada satu halaman }\end{array}$ \\
\hline & $\begin{array}{l}\text { OFF PAGE } \\
\text { CONNECTOR }\end{array}$ & $\begin{array}{l}\text { Penghubung bagian-bagian flowchart } \\
\text { yang berada pada halaman berbeda }\end{array}$ \\
\hline
\end{tabular}

Simbol - simbol Flow chart

Contoh Flow chart untuk menentukan bilangan terkecil

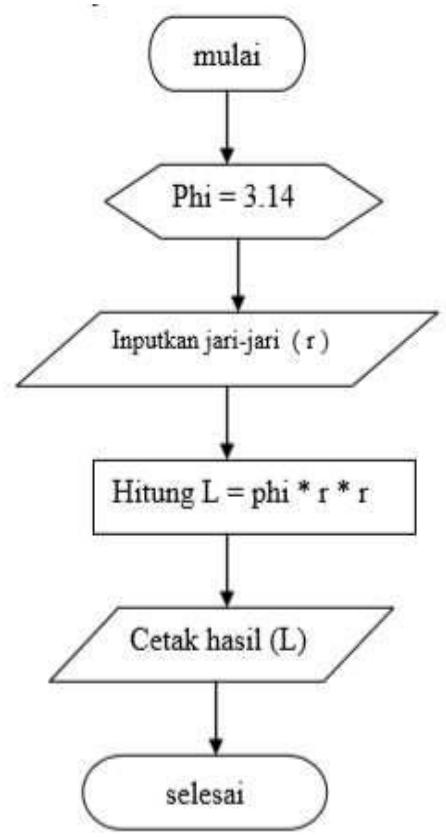

Gambar Flowchart Dengan Struktur Runtunan

Diawali dengan simbol terminal 'mulai', kemudian symbol untuk menentukan harga awal yaitu phi $=3.14$, dilanjutkan memasukkan variabel $r$ (jari-jari), dan 
dihitung dengan rumus $\mathrm{L}=\mathrm{phi} * \mathrm{r} * \mathrm{r}$, kemudian mencetak hasilnya (yang disimpan dalam variabel $\mathrm{L}$ ), terakhir terminal selesai.

Contoh berikutnya di bawah ini juga menggunakan flowchart dengan struktur runtunan untuk persoalan menonton film di rumah.

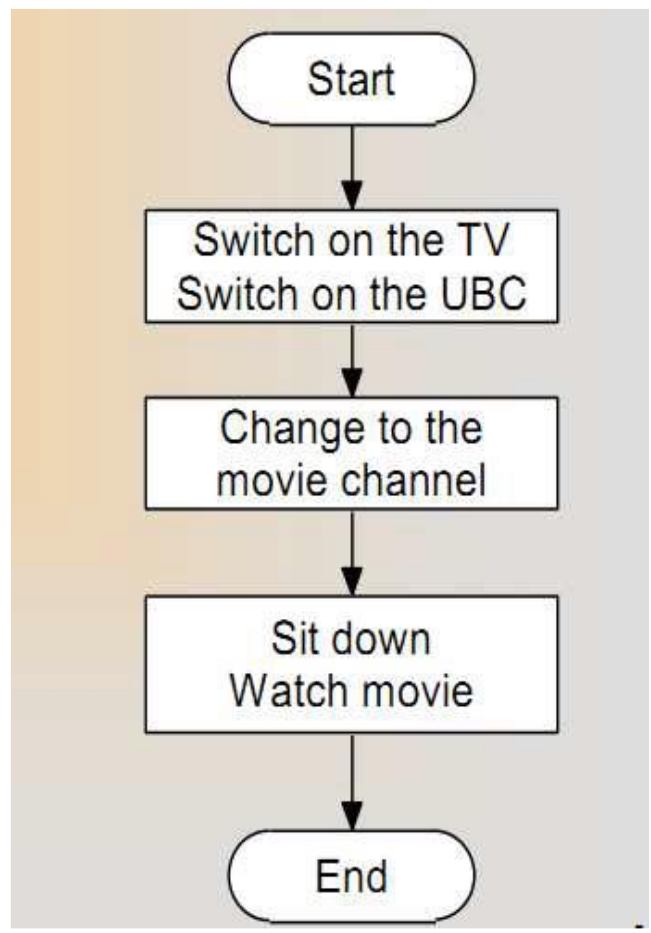

\section{Struktur Dasar Algoritma}

Terdapat tiga unsur dasar dalam algoritma, yaitu runtunan, pemilihan dan pengulangan. Dari ketiga jenis dapat membentuk struktur suatu algoritma. Berikut adalah penjelasan dari tiga struktur tersebut :

\section{Runtunan (sequence)}

Suatu runtunan memiliki intrukusi satu atau bisa juga lebih. Urutan Dari tugas ini yang menetapakan akhiran dari algoritma. Jika penulisan urutannya berubah maka hasil akhirnya pun akan ikut berubah.

Dapat dilihat contoh berikut ini operasi aritmatika berikut ini, $(4+3) * 7=49$, tetapi bila urutan aksinya diubah maka hasil keluaran akan berbeda menjadi $4+(3 * 7)=25$.

\section{Pemilihan (selection)}

Terkadang terletak suatu masalah yang akan baru diselesaikan jika dalam suatu kondisi sudah memungkinkan. Kondisi tersebutlah yang akan menilai benar atau salahnya suatu intruksi. Intruksi hanya bisa dilakukan 
jika bernilai benar. Begitupun sebaliknya jika intruksi bernilai salah maka tidak akan dilakukan.

Contoh dari kasus ini ialah penentuan bilangan genap atau ganjil sebagi berikut:

- Masukkan bilangan sebagai sebuah bilangan bulat

- Bagi bilangan dengan angka 2, simpan nilai sisa pembagian dalam variabel sisa

- Jika nilai sisa sama dengan 0 maka kerjakan langkah 4:

- Tampilkan "GENAP" ke layar

- Jika nilai sisa tidak sama dengan 0 maka kerjakan langkah 6

- Tampilkan "GANJIL" ke layar

- Selesai.

\section{Pengulangan (repetition)}

Salah satu kelebihan computer ialah mampu mengulang pekerjaan tanpa mengenal sama sekali. Pengulangan adalah suatu kegiatan di mana satu perilaku atau kembaran ganda mencapai jumlah tertentu atau sesuai dengan kondisi yang dipersyaratkan. Contohnya adalah menampilkan huruf-huruf tertentu n kali di layar, seperti gambar di bawah ini:

- Mendeklarasikan variabel alfabet untuk menyimpan karakter yang akan ditampilkan

- Deklarasikan variabel n untuk menyimpan jumlah banyaknya iterasi

- Deklarasi variabel penghitung yang digunakan sebagai penghitung yang telah selesai

- Masukkan karakter dan simpan dalam variabel abjad

- Mengatur nilai penghitung ke 0

- Menampilkan huruf ke layar

- Melakukan hal peningkatan dalam penghitung sebesar 1

- Jika nilai counter < n, lanjutkan ke langkah 6

- $\quad$ Jika nilai penghitung $=\mathrm{n}$

- $\quad$ selesai

\section{Pembelajaran Pemrograman Komputer}


Definisi pemrograman komputer adalah menulis, menguji dan memperbaiki (debugging) dan memelihara tanda pembuatan program. Saat menulis kode di komputer, ada banyak bahasa pemrograman. Jadi tujuan belajar pemrograman komputer adalah untuk menerbitkan program yang dapat melakukan perhitungan sesuai dengan kebutuhan programmer. Untuk dapat memprogram, kita harus memiliki keterampilan pemrograman, algoritma, logika, bahasa pemrograman, dan pengetahuan dalam banyak situasi lainnya., seperti matematika.

Purnamasari (2005:2) menyatakan bahwa untuk menunjukkan standar perencanaan yang baik memerlukan beberapa standar sebagai dasar evaluasi, seperti keterampilan pemecahan masalah dan pemrograman.

Di antara dalam mengatasi teknik pemecahan masalah standar, teknik topdown adalah salah satu metode pemecahan masalah yang paling umum. Masalah yang kompleks dibagi menjadi beberapa tingkatan kelompok, yang menjadi bagian terkecil dari sub kelompok. Setelah itu baru susun langkah-langkahnya Lengkap dengan detail. Langkah-langkah rinci sering itu disebut algoritma.

Proses dari masalah ke algoritma disebut fase solusi masalah, dan tahapan dari algoritma ke solusi disebut Fase implementasi. Solusi untuk masalah ini adalah program Implementasi dari algoritma kompilasi. Berikutnya adalah standar pemrograman. Beberapa faktor akan menjadi Standar pemrograman, meliputi:

1. logika dan penulisan kebenaran

2. Waktu tersingkat untuk pemrograman;

3. Kecepatan eksekusi tertinggi Program;

4. Mengekspresikan penggunaan memori.

\section{Prosedur dan Fungsi Algoritma}

Prosedur tersebut merupakan program mandiri dalam bloknya sendiri dan digunakan sebagai sub program (bagian program). Ini dimulai dengan kata alternatif "program" di bagian deklarasi program. Prosesnya biasanya berupa kegiatan, seperti menghitung luas, menghitung faktorial, mencari nilai tertinggi/terendah, dll. Prosedur sering dipakai dalam program terstruktur karena:

1. Merupakan aplikasi dari konsep program modular, yaitu menguraikan program yang kompleks menjadi bagian-bagian yang lebih sederhana dalam bentuk program. 
2. Keseringan dalam mengulang suatu hal, cukup satu kalisaja ditulikan dalam program, dan dapat dipanggil atau digunakan sewaktu-waktu bila diperlukan.

3. Mewujudkan sebuah kode programa untuk lebih gambah dibaca

4. Dapat dipakai untuk menyembunyikan detail program

Perbedaan antara fungsi dan prosedur adalah:

1. Dalam suatu fungsi, nilai kembalian ada dalam nama fungsi (jika parameter dilewatkan dengan referensi dalam prosedur).

2. Karena nilai yang dikembalikan ada pada nama fungsi, Anda dapat langsung menggunakan fungsi tersebut untuk mencetak hasilnya. Atau Anda bisa langsung meneruskan nilai fungsi ke pengenal variabel lain.

3. Dalam program, nama program tidak dapat digunakan secara langsung, tetapi parameter yang berisi nilai balik dapat digunakan secara langsung.

\section{Perbedaan Algoritma dan Pemrograman}

Bahasa pemrograman dan algoritma sangat erat kaitannya dengan sebuah program. Algoritma yang baik tidak memilih struktur data yang benar akan membuat program menjadi Tidak baik, begitu pula sebaliknya. Jika dikaitkan dengan program, gunakan Algoritma harus mematuhi aturan berikut:

1. Membuat atau menulis algoritma tidak bergantung pada bahasa. Ini berarti bahwa algoritme ditulis secara independen dari bahasa pemrograman dan Komputer yang menanganinya.

2. Notas algoritma diterjemahkan ke dalam bahasa pemrograman

3. Segala hal bahasa perograman. Outputnya tetap sama karena algoritmanya sama.

\section{PENUTUP}

\section{Kesimpulan}

Algoritma merupakan istilah dari "algoritma" yang berasal dari matematikan Muslim bernama Ibnu Kharazmi. Beliau hidup di abad ke-19. Dalam perkembangannya, ide ide yang dia milioi jelas dan dalam menyelesaikan masalah 
secara logis diterapkan sebagai metode algoritma dalam matematika proses kerja komputer.

Algoritma merupakan serangkaian langkah yg bersifat logis dalam penyelesain masalah yg tersusun secara sistematis. Bisa dibilang sebuah proses itu terintegras. atau metode khusus yang digunakan memecahkan masalah nyata. Algoritma merupakan langkah langkah dengan menyusun secara tertulis dan berurutam untuk mengakhiri suatu persoalan ataupun masalah. Sedangkan algoritma pemrograman merupakan langkah-langkah yang ditulis dengan berurutan dalam menyelesaikan suatu persoalan yang ada dalam pemrograman komputer.

Pemrograman yang sederhana dalam algoritma adalah langkah awal yang wajib ditulis sebelum menulis program. Masalah yang diselesaikan dnegan programan komputer adalah masalah yg berhubungan dengan perhitungan matematik.

Penerapan pembuatan algoritma dalam setiap penyelesaian soal pemrograman dapat membantu mahasiswa memahami konsep algoritma pemrograman dengan baik sehingga tidak banyak melakukan kesalahan dalam pembuatan program komputer.

Pemrograman merupakan suatu proses yang digunakan untuk mengimplementasikan suatu algoritma dengan menggunakan bahasa-bahasa yang sudah ada dalam sistem pemrograman (Budi, 2000:21). Tujuan dari pemrograman adalah agar dalam membuat suatu program, dapat melakukan suatu perhitungan atau pekerjaan sesuai dengan keinginan. Maka dari itu untuk melakukan pemrograman, sangat diperlukan keterampilan dalam algoritma.

Kata pemograman berasal dari kata program yang artinya serangkaian instruksi yang dituliskan dalam melakukan suatu hal fungsi spesifik pada komputer, sedangkan pemograman adalah segala kegiatan pembuatan program menggunakan komputer. Komputer membutuhkan keberadaan program agar bias menjalankan fungsinya sebagai komputer.

Bahasa pemrograman memiliki beberapa karakteristik, yaitu:

1. Memiliki tata bahasa dan aturan tertentu dalam penulisan perintah dan struktur program, pendeklarasian, serta pengoperasian translatornya. 
2. Memiliki pustaka interupsi (interrupt library) untuk menerjemahkan perintah yang di inputkan, dan

3. Menggunakan translator yaitu interpreter atau compiler untuk menerjemahkan sintaks pemrograman ke dalam bahasa mesin komputer.

\section{DAFTAR PUSTAKA}

Ardyan, Stephanus, Mulyono dan Amin Suyitno. 2017. Implementasi Algoritma Dijkstra Dalam Pencarian Rute Terpendek Tempat Wisata di Kabupaten Gunungkidul Dengan Program Visual Basic. Jurnal Matematika FMIPA. Vo. 6, No. 2.

Bagus, Kadek dan Teristha Udayana. 2018. Penrapan Komponen dan Struktur Algoritma Pada Algoritma dan Pemrograman Dasar. Jurnal Bisnis dan Teknologi Politeknik. Vol. 5, No. 1.

Barakbah, Alin Ridho, Tita Karlita dan Ahmad Syauqi Ahsan. 2013. Logika dan Algoritma. Surabaya: Politeknik Elektronika Negeri Surabaya.

Chairunnas, Andi. 2017. Penerapan Algoritma Tripod Gait Pada Robot Hexapod Menggunakan Arduino Mega 128. Jurnal Penelitian Pos dan Informatika. Vol. 7, No.1, Hal: 37-48.

Indahyanti, Uce dan Yunianita Rahmawati. 2020. Algoritma Pemrograman Dalam Bahasa $C++$. Jawab Timur: UMSIDA Press.

Isroqmi, Asnurul. 2017. Kemampuan Mahasiwa Memahami Logika Pemrograman Komputer Melalui Algoritma. Jurnal Pendidikan Matematika. Vol. 2, No.2.

Julianto, Ahmad Kamal Asri dan Ekohariadi. 2020. Metode Gamication Pada Pemrograman Dasar Teknik Komputer dan Informatika di Sekolah Menengah Kejuruan, Jurnal IT-EDU. Vol. 5, No. 1, Hal: 77-84.

Maulana, Gun Gun. 2017. Pembelajaran Dasar Algoritma dan Pemrograman Menggunakan El-Goritma Berbasi Web. Jurnal Teknik Mesin. Vol. 6, No. 2.

Naufal, Mohammad Farid. 2018. Analisis Teknik Pembelajaran dan Pengajaran Pemrograman Pada Universitas dan Industri. Jurnal Informatika dan Multimedia. Vol. 10, No. 2. 
Retta, Allen Marga, Asnurul Isroqmi dan Tika Dwwi Nopriyanti. 2016. Pengaruh Penerapan Algoritma Terhadap Pembelajaran Pemrograman Komputer. Jurnal Inovasi Pendidikan Matematika. Vol. 02, No. 2, Hal: 126-135.

Samsudin, Indrawan dan Sri Mulyanti. 2020. Perancangan Sistem Informasi Pembelajaran Algoritma dan Pemrograman Berbasis Web Pada Program Studi Teknik Informatika STMIK ERESHA. Jurnal Informatika. Vol. 5, No. 4, Hal: 521-528.

Suryadi dan Agus Salim. 1997. Pengantar Algoritma dan Pemrograman Teknik Diagram Alur dan Bahasa Basic Dasar. Depok: Gunadarma.

Yahfizham, Kasmana Rukun, Krismadinata, Ganefri, Sukardi dan Wizwardi Jalinus. 2018. Pembelajaran Pada Mata Kuliah Elektronika Daya: Suatu Kajian Literatur. Jurnal Pendidikan Teknologi dan Kejuruan. Vol. 15, No. 2, Hal: 157. 


\section{Artikel mutia algor by Mutia Mutia}

Submission date: 22-Oct-2021 01:12PM (UTC+0700)

Submission ID: 1680839204

File name: IKEL_ALGORITMA_FARAH_MUTIA_PUTRI_0305202017_PMM_2-dikonversi.pdf (296.88K) Word count: 3009

Character count: 20003 


\title{
KONSEP DASAR DALAM MEMPELAJARI MATA KULIAH \\ ALGORITMA PEMROGRAMAN
}

\author{
Farah Mutia Putri (0305202017) \\ Program Studi Pendidikan Matematika-2 \\ Fakultas Ilmu Tarbiyah dan Keguruan UIN Sumatera Utara \\ Jl. William Iskandar Pasar V, Medan Estate \\ Email: farahmutiaputri@gmail.com
}

\begin{abstract}
ABSTRAK
Dalam algoritma terdapat urutan langkah dalam menyelesaikan sebuah masalah. Langkah - angkah tersebut disusun secara sistematis. algoritma ialah suatu tata cara dalam mengurutkan langkah - langkah yang berintegrasi, penggunaan dalam menyelesaikan masalah memiliki metode khusus dalam penyelesai suatau masalah yg nyata(Webster Dictionary).

Algoritma memiliki tujan supaya kita dapat membiasakann diri dalam melaksanakan sistem perencanaan dari suatu masalah yang dihadapi. Dengan permasalahan tersebut dapat diselesaikan dengan perencanaan yang matang agar dalam menyelesaikan masalah kita dapat mengoptimalkan solusi yang tepat. Dengan begitu, penyelesaian masalah tidak bisa dilakukan tanpa menggunakan perencanaan. Pembelajaran suatu program sangat berbeda dengan pembelajaran suatu bahasa pemrograman. Saat pembelajaran program terdapat mengenai strategi tata cara dalam penyelesain sebuah masalah, masalah ini akan diungkapkan dalam wujud algortima yang sederhana mudah untuk dipahami dan dibaca sehingga dapat dituangkan lebih lanjut kedalam bahasa pemrograman. Belajar membuat program adalah belajar tentang strategi atau cara menyelesaikan suatu masalah, yang diungkapkan dalam bentuk algoritma yang mudah dibaca dan dipahami yang selanjutnya dituangkan dalam bahasa pemrograman. Sifat dari mempelajari program yang memahami persoalan, analisa dan sintesis.
\end{abstract}

Kata Kunci : algoritma, program, pemrograman, bahasa, langkah-langkah

PENDAHULUAN 
Programa studi pendidikan matematika memiliki mata kuliah yang ditawarkan salah satunya merupakan algoritma pemrograman. Dalam mata kuliah ini bertujuan untuk mengetahui konsep dasar pemrograman melalui algoritma, langkah - langkah algoritma serta bagaimana cara menerapkan algoritma daalm sistem pemrograman.

Saat menjalankan aktivitas kita tidak bisa lepas dari algoritma. Bisa dibilang algoritma merupakan panduan ataupun solusi yang dilakukan secara sistematis dalam menjalani atau menghadapi berbagai macam masalah yang ada disekitar. Adapun setiap langkah yang dilakukan dalam menyelesaikan sebuah permasalahan dapat dilaksanakan dengan berbagai cara beserta karakteristik yang berbeda beda di setiap masing-masing langkah.

Definisi algoritma dapat dikatakan Sebagai rangkaian langkah logis dan sistematis untuk mencari solusi dari permasalahan yang ada. Menurut Rinaldi Munir (2002), algoritma adalah serangkaian langkah logis yang diounakan untuk menyelesaikan suatu masalah, dan langkah - langkah tersebut disusun secara sistematis. Sedangkan menurut Levitin (Rinaldi, 2007:4), algoritma adalah serangkaian instruksi eksplisit untuk memecahkan masalah, memperoleh keluaran yang diinginkan dari sejumlah masukan yang terbatas.

Belajar algoritma hampir sama dengan belajar matematika, jika dalam matematika kita harus memahami rumus terlebih dahulu sebelum bisa mendapatkan hasil soal, begitu juga dengan algoritma dan prosedur, kita harus terlebih dahulu memahami kode - kode tertentu yang disebut coding agar kita dapat menjalankan program dan menuangkannya ke dalam beberapa jenis simbol yang mudah dibaca dan dipahami.

Algoritma mempunyai beberapa karakteristik, yaitu :

1. Menerima beberapa masukan.

2. Memproses masukan melalui langkah-langkah yangberurutan.

3. Setiap langkah harus didefinisikan dengan jelas, sederhana, danefektif.Urutan langkah tersebut harus terbatas dan berhenti.Menghasilkan keluaran atau output.

Pemrograman adalah proses implementasi algoritma dengan menggunakan bahasa yang sudah ada dalam sistem pemrograman (Budi, 2000:21). Tujuan 
pemrograman adalah kita dapat melakukan perhitungan atau pekerjaan sesuai kebutuhan saat menulis program. Oleh karena itu, untuk memprogram, kita memerlukan keterampilan algoritma.

Pemrograman berasal dari kata "program", yang berarti serangkaian instruksi yang ditulis untuk melakukan fungsi tertentu pada komputer, dan pemrograman adalah aktivitas apa pun yang digunakan komputer untuk membuat program. Sebuah komputer membutuhkan program untuk menjalankan fungsinya sebagai komputer.

Bahasa pemrograman memiliki beberapa ciri, yaitu:

1. Memiliki tata bahasa dan aturan tertentu dalam penulisan perintah dan struktur program, pendeklarasian, sertapengoperasian translatornya.

2. Terdapat perpustakaan interupsi untuk menerjemahkan perintah input, dan

3. Gunakan penerjemah, yaitu juru bahasa atau kompiler, untuk menerjemahkan tata bahasa pemrograman ke dalam bahasa mesin komputer.

Dalam pemrograman, bahasa yang disebut turing complete dapat digunakan untuk menggambarkan semua perhitungan yang dilakukan oleh mesin Turing. Mesin Turing memiliki variabel integer dan operator aritmatika, pernyataan penugasan, pernyataan sekuensial, pernyataan pemilihan, dan pernyataan iterasi. Pernyataan-pernyataan tersebut digunakan mesin Turing didefinisikan secara formal oleh konsep matematika.

\section{Studi Literatur}

Istilah algoritma berasal dari istilah "algoritma" dan mengacu pada Seorang matematikawan Muslim yang hidup pada abad ke-19 bernama Ibnu Kharazmi. Dalam perkembangannya, ide - idenya Jelaskan dan selesaikan masalah secara logis diterapkan sebagai metode algoritma dalam matematika Proses kerja komputer.

Di dalam penelitian ini akan dijelaskan mengenai pengertian algoritma, konsep algoritma, notasi algoritma,ciri, sifat dan struktur dasar dalam pembelajaran algoritma beserta langkah langkah dalam pengerjaan algoritma pemrograman . Penelitain ini juga akan menjelaskan mengenai apa saja perbedan algoritma 
dengan pemrograman dan dari perbedaan tersebut akan dijelaskan hubungan antara algoritma pemrograman.

\section{Metode Penelitian}

Metode yang digunakan dalam penelitian ini berasal dari buku sebagai referensi beserta jurnal yang diterbitkan. Dalam penelitian ini jurnal penelitian terkait dengan teori dan konsep dasar algoritma perograman, metode/teknik/strategi dalam algoritma pemrograman. Bentuk ringkasannya adalah algoritma dan bahasa yang ada di dalam pemrograman yang akan digunakan, strukukturnya, siapa objek penelitiannya, dan penerapan dalam kehidupan, beserta contoh-contoh teknik tersebut.

Ada beberapa ketentuan dalam mengerjakan menyelesaikan peneletian ini,yaitu:

1. Ketentuan pertama dalam penelitian ini harus memiliki referensi minimal 10 jurnal. Jurnal - jurnal tersebit harus terdapat beberapa tema yang sudah ditentukan. Selain itu, yang harus dipenuhi yaitu jurnal dimulai pada tahun 2015 .

2. Ketentuan kedua dalam penelitian ini harus memiliki refensi minimal dari 2 buku. Buku yang dipilih dalam renferensi penelitian ini yaitu pertama berjudul "Algortma \& Pemrograman Dalam Bahasa $\mathrm{C}++$, penulis buku ini ialah Uce Indahyanti, M.Kom danYunianita Rahmawati, M.Kom.. Buku kedua berjudul "Logika dan Algoritma", penulis buku ini ialah Ali Ridho Barakbah, S.Kom., PhD., Tita Karlita, S. Kom., M. Kom. Dan Ahmad Syauqi Ahsan, S. Kom. Di dalam buku terdapat materi mengenai materi algoritma pemrograman dan terdapat contoh - contoh penerapan algoritma dalam kehidupan.

3. Ketentuan ketiga dalam penilitian ini minimal kata yang ada dalam penelitian ini berjumlah 3000 kata.

\section{PEMBAHASAN}

\section{Algoritma}

24 Algoritma adalah sistem komputer yang memiliki perangkat otak (brainware), perangkat keras (hardware) dan perangkat lunak (software). Tanpa ketiga hal 
tersebut sistem komputer tidak akan berfungsi. Saat kita fokus memperhatikan perangkat lunak (software) komputer. Perangkat lunak ini dibangun di atas Struktur program dan tata bahasa (cara menulis/pemrograman). Menulis Prosedur atau tata bahasa, langkah - langkah yang diperlukan. Mampu secara sistematis dan logis. Masalah atau tujuan dalam proses pemecahan. Membuat perangkat lunak. Nah, algoritmanya. Memainkan peran penting dalam pemrograman Atau tata bahasa.

Algoritma yang paling penting memiliki dua struktur dasar, yaitu:

1. Gunakan sistem belajar mandiri (bahan belajar mandiri) dan simpan di komputer. Sehingga dosen dapat berkunjung kapan saja dan dimana saja.

2. Gunakan komputer untuk melihat kemajuan belajar, jadwal kurikulum, hasil kemajuan belajar, dan hal-hal yang berhubungan dengan pendidikan 28 setiap saat.

Algoritma adalah serangkaian langkah logis untuk memecahkan masalah Compose secara sistematis. Algoritma yang disebutkan dalam referensi lain adalah suatu proses, yang merupakan serangkaian langkah-langkah terintegrasi, atau metode khusus untuk memecahkan masalah praktis (Webster Kamus).

Kita juga telah melakukan algoritma dalam kehidupan kita sehari-hari, Seperti mengirim email, menginstal aplikasi, menerima pembayaran di ATM, isi ulang poin, buat kue, naik motor, dll.

Berikut beberapa contoh mengenai algoritma dikehidupan sehari-hari:

Contoh 1 : Mengendarai sepeda motor:

1. Mulai

2. Memasukkan Kunci

3. Menyalakan Mesin

4. Memasukkan Gigi Satu

5. Memutar Pegangan Gas

6. Menjalakan

7. Menaikkan Sepeda

Contoh 2 : Mengirim Email:

1. Mulai

2. Login ke situs layanan email sesuai 
3. Pilih tulis email (pesan baru)

4. Masukkan alamat mail tujuan, subjek dan tulis

Contoh 3 : Mengkoneksikan perangkat ke jaringan wifi

1. Mulai

2. Pilih jaringan wifi yang tersedia

3. Masukan username dan password

4. Jika tidak sesuai, sistem menampilkan gagal koneksi

5. Jika sesuai, koneksi internet dapat digunakan.

\section{Karakteristik ,Sifat, bentuk Dasar dan Cara Penulisan Algoritma}

Menurut Donald E. Knuth, algoritma memiliki lima karakteristik yang sangat penting, yaitu:

1. Finiteness (pembatasan), algoritma harus dihentikan setelah beberapa langkah proses telah dijalankan.

2. Definiteness (kepastian), semua tindakan harus dimaknai dengan benar, tidak berarti lebih darisatu.

3. Input (masukan), ada nol atau lebih data masukan (input) dalam algoritma.

4. Output (keluaran), terdapat algoritma memiliki nol atau lebih output

5. Effectiveness (efektivitas), langkah - langkah yang diambil saat meneliti algoritma harus tepat waktu dan berhasil.

Sedangkan sifat algoritma, yaitu:

1. Bahasa yang ada dalam pemrograman tidak menggunakan simbol/tata bahasa tertentu

2. Bahasa pemrograman tidak bergantung pada apapun

3. Seluruh bahasa dalam pemrograman dapat digunakan dalam notasinotasinya

4. Suatu algoritma dalam merepresentasikan dapat digunakan untuk kejadian yang diurutkan secara logisdan dapat diterapkan di semua kejadian seharihari.

\section{Notasi Algoritma}

Notasi algoritma tidak merupakan notasi perograman, tetapi notasi yang dapat dijadikan sebagai notasi perograman. Notasi dalam algoritma ada sebagian hal, diantaranya: 


\section{Untaian Kalimat Deskriptif (Natural)}

Algoritma deskriptif adalah algoritma yang ditulis dalam kalimat dalam bahasa manusia seperti bahasa Indonesia atau bahasa Inggris. Simbol semacam ini cocok untuk aritmatika pendek, tetapi untuk simbol yang panjang, efisiensi simbol semacam ini rendah, dan konversi simbol algoritme ke simbol bahasa pemrograman seringkali relatif sulit.

\section{Pseudocode}

Pseudo-code berasal dari kata "pseudo" dan "code". Pseudo mengacu pada imitasi, dan kode mengacu pada kode yang terkait dengan instruksi yang ditulis dalam bahasa komputer atau kode bahasa pemrograman. Kode semu digunakan untuk menggambarkan urutan logis dari program dan tidak ada hubungannya dengan bahasa pemrograman.

\section{Flow Chart (Diagram Alir)}

Flowchart atau bagan alir adalah diagram yang menggunakan simbol atau gambar tertentu dan garis alur untuk menggambarkan urutan langkah dari awal hingga akhir suatu kegiatan atau program. Simbol mewakili fungsi langkah-langkah program dan garis arus mewakili urutan simbol yang akan diproses. Diagram alir lebih baik digunakan daripada kode semu. Jumlah simbol yang digunakan dalam flowchart sedikit karena lebih sederhana dan lebih mudah dipelajari.

Tidak ada rumusan atau patokan yang mutlak untuk membuat diagram alir program, karena diagram alir merupakan gambaran dari hasil analisis masalah komputer, sehingga hasil diagram alir dapat berbeda-beda antara programmer satu dengan programmer lainnya. 


\begin{tabular}{|c|c|c|}
\hline SIMBOL & NAMA & FUNGSI \\
\hline & TERMINATOR & Permulaan/akhir program \\
\hline & $\begin{array}{l}\text { GARIS ALIR } \\
\text { (FLOW LINE) }\end{array}$ & Arah aliran program \\
\hline & PREPARATION & $\begin{array}{c}\text { Proses inisialisasi/pemberian harga } \\
\text { awal }\end{array}$ \\
\hline & PROSES & $\begin{array}{c}\text { Proses perhitungan/proses pengolahan } \\
\text { data }\end{array}$ \\
\hline & $\begin{array}{l}\text { INPUT/OUTPUT } \\
\text { DATA }\end{array}$ & $\begin{array}{l}\text { Proses input/output data, parameter, } \\
\text { informasi }\end{array}$ \\
\hline & DECISION & $\begin{array}{l}\text { Perbandingan pernyataan, penyeleksian } \\
\text { data yang memberikan pilihan untuk } \\
\text { langkah selanjutnya }\end{array}$ \\
\hline & $\begin{array}{c}\text { ON PAGE } \\
\text { CONNECTOR }\end{array}$ & $\begin{array}{l}\text { Penghubung bagian-bagian flowchart } \\
\text { yang berada pada satu halaman }\end{array}$ \\
\hline & $\begin{array}{c}\text { OFF PAGE } \\
\text { CONNECTOR }\end{array}$ & $\begin{array}{l}\text { Penghubung bagian-bagian flowchart } \\
\text { yang berada pada halaman berbeda }\end{array}$ \\
\hline
\end{tabular}

Simbol - simbol Flow chart

Contoh Flow chart untuk menentukan bilangan terkecil

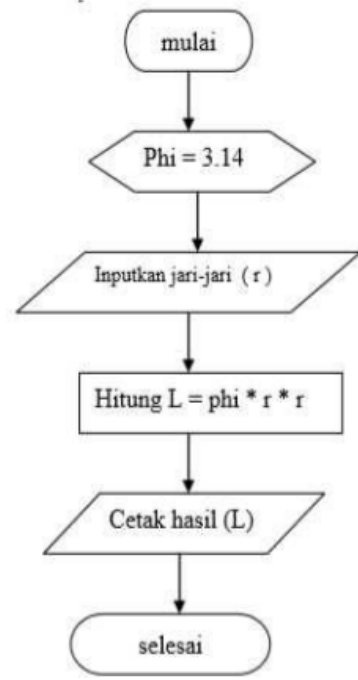

Gambar Flowchart Dengan Struktur Runtunan

Diawali dengan simbol terminal 'mulai', kemudian symbol untuk menentukan harga awal yaitu phi $=3.14$, dilanjutkan memasukkan variabel $\mathrm{r}$ (jari-jari), dan 
dihitung dengan rumus $\mathrm{L}=\mathrm{phi} * \mathrm{r} * \mathrm{r}$, kemudian mencetak hasilnya (yang disimpan dalam variabel $\mathrm{L}$ ), terakhir terminal selesai.

Contoh berikutnya di bawah ini juga menggunakan flowchart dengan struktur runtunan untuk persoalan menonton film di rumah.

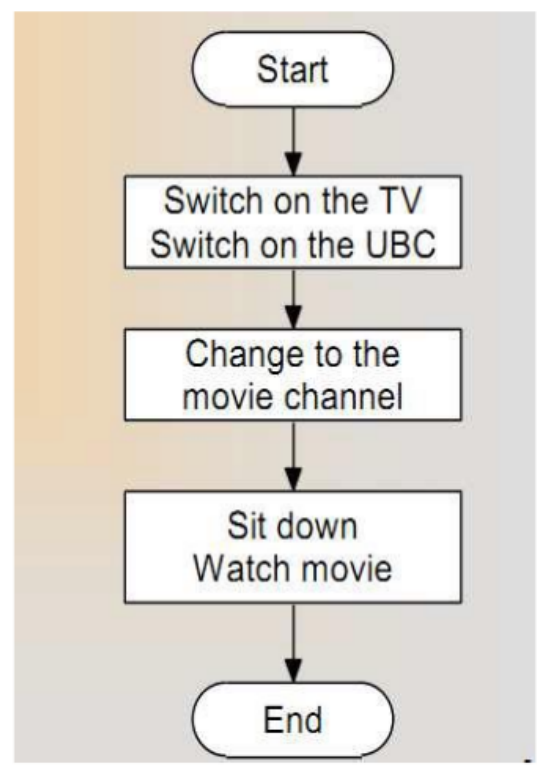

\section{Struktur Dasar Algoritma}

Terdapat tiga unsur dasar dalam algoritma, yaitu runtunan, pemilihan dan pengulangan. Dari ketiga jenis dapat membentuk struktur suatu algoritma. Berikut adalah penjelasan dari tiga struktur tersebut :

\section{Runtunan (sequence)}

Suatu runtunan memiliki intrukusi satu atau bisa juga lebih. Urutan Dari tugas ini yang menetapakan akhiran dari algoritma. Jika penulisan urutannya berubah maka hasil akhirnya pun akan ikut berubah.

Dapat dilihat contoh berikut ini operasi aritmatika berikut ini, $(4+3) * 7=49$, tetapi bila urutan aksinya diubah maka hasil keluaran akan berbeda menjadi $4+(3 * 7)=25$.

\section{Pemilihan (selection)}

Terkadang terletak suatu masalah yang akan baru diselesaikan jika dalam suatu kondisi sudah memungkinkan. Kondisi tersebutlah yang akan menilai benar atau salahnya suatu intruksi. Intruksi hanya bisa dilakukan 
27

jika bernilai benar. Begitupun sebaliknya jika intruksi bernilai salah maka tidak akan dilakukan.

Contoh dari kasus ini ialah penentuan bilangan genap atau ganjil sebagi berikut:

- Masukkan bilangan sebagai sebuah bilangan bulat

- Bagi bilangan dengan angka 2, simpan nilai sisa pembagian dalam variabel sisa

- Jika nilai sisa sama dengan 0 maka kerjakan langkah 4:

- Tampilkan "GENAP" ke layar

- Jika nilai sisa tidak sama dengan 0 maka kerjakan langkah 6

- Tampilkan "GANJIL" ke layar

- Selesai.

\section{Pengulangan (repetition)}

Salah satu kelebihan computer ialah mampu mengulang pekerjaan tanpa mengenal sama sekali. Pengulangan adalah suatu kegiatan di mana satu perilaku atau kembaran ganda mencapai jumlah tertentu atau sesuai dengan kondisi yang dipersyaratkan. Contohnya adalah menampilkan huruf-huruf tertentu n kali di layar, seperti gambar di bawah ini:

- Mendeklarasikan variabel alfabet untuk menyimpan karakter yang akan ditampilkan

- Deklarasikan variabel n untuk menyimpan jumlah banyaknya iterasi

- Deklarasi variabel penghitung yang digunakan sebagai penghitung yang telah selesai

- Masukkan karakter dan simpan dalam variabel abjad

- Mengatur nilai penghitung ke 0

- Menampilkan huruf ke layar

- Melakukan hal peningkatan dalam penghitung sebesar 1

- Jika nilai counter $<\mathrm{n}$, lanjutkan ke langkah 6

- Jika nilai penghitung $=\mathrm{n}$

- selesai

Pembelajaran Pemrograman Komputer 
Definisi pemrograman komputer adalah menulis, menguji dan memperbaiki (debugging) dan memelihara tanda pembuatan program. Saat menulis kode di komputer, ada banyak bahasa pemrograman. Jadi tujuan belajar pemrograman komputer adalah untuk menerbitkan program yang dapat melakukan perhitungan sesuai dengan kebutuhan programmer. Untuk danat memprogram, kita harus memiliki keterampilan pemrograman, algoritma, logika, bahasa pemrograman, dan pengetahuan dalam banyak situasi lainnya., seperti matematika.

Purnamasari (2005:2) menyatakan bahwa untuk menunjukkan standar perencanaan yang baik memerlukan beberapa standar sebagai dasar evaluasi, seperti keterampilan pemecahan masalah dan pemrograman.

Di antara dalam mengatasi teknik pemecahan masalah standar, teknik topdown adalah salah satu metode pemecahan masalah yang paling umum. Masalah yang kompleks dibagi menjadi beberapa tingkatan kelompok, yang menjadi bagian terkecil dari sub kelompok. Setelah itu baru susun langkah-langkahnya Lengkap dengan detail. Langkah-langkah rinci sering itu disebut algoritma.

Proses dari masalah ke algoritma disebut fase solusi masalah, dan tahapan dari algoritma ke solusi disebut Fase implementasi. Solusi untuk masalah ini adalah program Implementasi dari algoritma kompilasi. Berikutnya adalah standar pemrograman. Beberapa faktor akan menjadi Standar pemrograman, meliputi:

1. logika dan penulisan kebenaran

2. Waktu tersingkat untuk pemrograman;

3. Kecepatan eksekusi tertinggi Program;

4. Mengekspresikan penggunaan memori.

\section{Prosedur dan Fungsi Algoritma}

Prosedur tersebut merupakan program mandiri dalam bloknya sendiri dan digunakan sebagai sub program (bagian program). Ini dimulai dengan kata alternatif "program" di bagian deklarasi program. Prosesnya biasanya berupa kegiatan, seperti menghitung luas, menghitung faktorial, mencari nilai tertinggi/terendah, dll. Prosedur sering dipakai dalam program terstruktur karena:

1. Merupakan aplikasi dari konsep program modular, yaitu menguraikan program yang kompleks menjadi bagian-bagian yang lebih sederhana dalam bentuk program. 
2. Keseringan dalam mengulang suatu hal, cukup satu kalisaja ditulikan dalam program, dan dapat dipanggil atau digunakan sewaktu-waktu bila diperlukan.

3. Mewujudkan sebuah kode programa untuk lebih gambah dibaca

4. Dapat dipakai untuk menyembunyikan detail program

Perbedaan antara fungsi dan prosedur adalah:

1. Dalam suatu fungsi, nilai kembalian ada dalam nama fungsi (jika parameter dilewatkan dengan referensi dalam prosedur).

2. Karena nilai yang dikembalikan ada pada nama fungsi, Anda dapat langsung menggunakan fungsi tersebut untuk mencetak hasilnya. Atau Anda bisa langsung meneruskan nilai fungsi ke pengenal variabel lain.

3. Dalam program, nama program tidak dapat digunakan secara langsung, tetapi parameter yang berisi nilai balik dapat digunakan secara langsung.

\section{Perbedaan Algoritma dan Pemrograman}

Bahasa pemrograman dan algoritma sangat erat kaitannya dengan sebuah program. Algoritma yang baik tidak memilih struktur data yang benar akan membuat program menjadi Tidak baik, begitu pula sebaliknya. Jika dikaitkan dengan program, gunakan Algoritma harus mematuhi aturan berikut:

1. Membuat atau menulis algoritma tidak bergantung pada bahasa. Ini berarti bahwa algoritme ditulis secara independen dari bahasa pemrograman dan Komputer yang menanganinya.

2. Notas algoritma diterjemahkan ke dalam bahasa pemrograman

3. Segala hal bahasa perograman. Outputnya tetap sama karena algoritmanya sama.

\section{PENUTUP}

\section{Kesimpulan}

Algoritma merupakan istilah dari "algoritma" yang berasal dari matematikan Muslim bernama Ibnu Kharazmi. Beliau hidup di abad ke-19. Dalam perkembangannya, ide ide yang dia milioi jelas dan dalam menyelesaikan masalah 
secara logis diterapkan sebagai metode algoritma dalam matematika proses kerja komputer.

Algoritma merupakan serangkaian langkah yg bersifat logis dalam penyelesain masalah yg tersusun secara sistematis. Bisa dibilang sebuah proses itu terintegras. atau metode khusus yang digunakan memecahkan masalah nyata. Algoritma merupakan langkah langkah dengan menyusun secara tertulis dan berurutam untuk mengakhiri suatu persoalan ataupun masalah. Sedangkan algoritma pemrograman merupakan langkah-langkah yang ditulis dengan berurutan dalam menyelesaikan suatu persoalan yang ada dalam pemrograman komputer.

Pemrograman yang sederhana dalam algoritma adalah langkah awal yang wajib ditulis sebelum menulis program. Masalah yang diselesaikan dnegan programan komputer adalah masalah yg berhubungan dengan perhitungan matematik.

Penerapan pembuatan algoritma dalam setiap penyelesaian soal pemrograman dapat membantu mahasiswa memahami konsep algoritma pemrograman dengan baik sehingga tidak banyak melakukan kesalahan dalam pembuatan program komputer.

Pemrograman merupakan suatu proses yang digunakan untuk mengimplementasikan suatu algoritma dengan menggunakan bahasa-bahasa yang sudah ada dalam sistem pemrograman (Budi, 2000:21). Tujuan dari pemrograman adalah agar dalam membuat suatu program, dapat melakukan suatu perhitungan atau pekerjaan sesuai dengan keinginan. Maka dari itu untuk melakukan pemrograman, sangat diperlukan keterampilan dalam algoritma.

Kata pemograman berasal dari kata program yang artinya serangkaian instruksi yang dituliskan dalam melakukan suatu hal fungsi spesifik pada komputer, sedangkan pemograman adalah segala kegiatan pembuatan program menggunakan komputer. Komputer membutuhkan keberadaan program agar bias menjalankan fungsinya sebagai komputer.

Bahasa pemrograman memiliki beberapa karakteristik, yaitu:

1. Memiliki tata bahasa dan aturan tertentu dalam penulisan perintah dan struktur program, pendeklarasian, serta pengoperasian translatornya. 
2. Memiliki pustaka interupsi (interrupt library) untuk menerjemahkan perintah yang di inputkan, dan

3. Menggunakan translator yaitu interpreter atau compiler untuk menerjemahkan sintaks pemrograman ke dalam bahasa mesin komputer.

\section{DAFTAR PUSTAKA}

Ardyan, Stephanus, Mulyono dan Amin Suyitno. 2017. Implementasi Algoritma Dijkstra Dalam Pencarian Rute Terpendek Tempat Wisata di Kabupaten Gunungkidul Dengan Program Visual Basic. Jurnal Matematika FMIPA. Vo. 6, No. 2 .

Bagus, Kadek dan Teristha Udayana. 2018. Penrapan Komponen dan Struktur Algoritma Pada Algoritma dan Pemrograman Dasar. Jurnal Bisnis dan Teknologi Politeknik. Vol. 5, No. 1.

Barakbah, Alin Ridho, Tita Karlita dan Ahmad Syauqi Ahsan. 2013. Logika dan Algoritma. Surabava: Politeknik Elektronika Negeri Surabaya.

Chairunnas, Andi. 2017. Penerapan Algoritma Tripod Gait Pada Robot Hexapod Menggunakan Arduino Mega 128. Jurnal Penelitian Pos dan Informatika. Vol. 7, No.1, Hal: 37-48.

Indahyanti, Uce dan Yunianita Rahmawati. 2020. Algoritma Pemrograman Dalam Bahasa $C++$. Jawab Timur: UMSIDA Press.

Isroqmi, Asnurul. 2017. Kemampuan Mahasiwa Memahami Logika Pemrograman Komputer Melalui Algoritma. Jurnal Pendidikan Matematika. Vol. 2, No.2.

Julianto, Ahmad Kamal Asri dan Ekohariadi. 2020. Metode Gamication Pada Pemrograman Dasar Teknik Komputer dan Informatika di Sekolah Menengah Kejuruan, Jurnal IT-EDU. Vol. 5, No. 1, Hal: 77-84.

Maulana, Gun Gun. 2017. Pembelajaran Dasar Algoritma dan Pemrograman Menggunakan El-Goritma Berbasi Web. Jurnal Teknik Mesin. Vol. 6, No. 2.

Naufal, Mohammad Farid. 2018. Analisis Teknik Pembelajaran dan Pengajaran Pemrograman Pada Universitas dan Industri. Jurnal Informatika dan Multimedia. Vol. 10, No. 2. 
Retta, Allen Marga, Asnurul Isroqmi dan Tika Dwwi Nopriyanti. 2016. Pengaruh Penerapan Algoritma Terhadap Pembelajaran Pemrograman Komputer. Jurnal Inovasi Pendidikan Matematika. Vol. 02, No. 2, Hal: 126-135.

Samsudin, Indrawan dan Sri Mulyanti. 2020. Perancangan Sistem Informasi Pembelajaran Algoritma dan Pemrograman Berbasis Web Pada Program Studi Teknik Informatika STMIK ERESHA. Jurnal Informatika. Vol. 5, No. 4, Hal: 521-528.

Suryadi dan Agus Salim. 1997. Pengantar Algoritma dan Pemrograman Teknik Diagram Alur dan Bahasa Basic Dasar. Depok: Gunadarma.

Yahfizham, Kasmana Rukun, Krismadinata, Ganefri, Sukardi dan Wizwardi Jalinus. 2018. Pembelajaran Pada Mata Kuliah Elektronika Daya: Suatu Kajian Literatur. Jurnal Pendidikan Teknologi dan Kejuruan. Vol. 15, No. 2, Hal: 157. 
Artikel mutia algor

ORIGINALITY REPORT

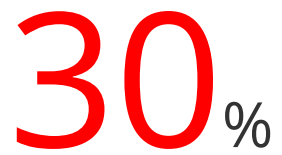

SIMILARITY INDEX
$29 \%$

INTERNET SOURCES
$2 \%$

PUBLICATIONS
$7 \%$

STUDENT PAPERS

PRIMARY SOURCES

1 www.jurnal.umuslim.ac.id

Internet Source

$6 \%$

2 belajarkodingbersama.files.wordpress.com Internet Source

3 ejournal.unitaspalembang.ac.id Internet Source

4 jurnal.univpgri-palembang.ac.id

Internet Source

5 es.scribd.com

Internet Source

6 WWw.simonmurd.com

Internet Source

7 fr.scribd.com

Internet Source

8

pradiptaagus.blogspot.com

Internet Source 
10 gatotwidodo.wordpress.com

11 ejournal.unesa.ac.id

12 jurnal.dharmawangsa.ac.id

Internet Source

13 repository.ubaya.ac.id

Internet Source

14 repository.radenintan.ac.id Internet Source

15 tekniktransmisitelekomunikasi.blogspot.com Internet Source

16 jurnal-ppi.kominfo.go.id Internet Source

17 www.ngopot.com

Internet Source

text-id.123dok.com

Internet Source

19 Submitted to STT PLN

Student Paper

20 muhamad4rif.simplesite.com 
22 andichristiandotblog.files.wordpress.com

23 journal.undiknas.ac.id

24 garudacyber.co.id

25 staim-bandung.ac.id

26 babygals.wordpress.com

27 blogbugabagi.blogspot.com 